\begin{tabular}{|c|l|}
\hline Title & $\begin{array}{l}\text { Leaching behaviour of elements and eval uation of pre treatment methods for municipal solid waste incinerator residues } \\
\text { in column leaching tests. }\end{array}$ \\
\hline Author(s) & Kim, Sang-Yul; T anaka, Nobutoshi; Matsuto, Toshihiko; Tojo, Y asumasa \\
\hline Citation & $\begin{array}{l}\text { Waste Management and Research, 23(3), 220-229 } \\
\text { https://doi.org/10.1177/0734242X 05055322 }\end{array}$ \\
\hline Issue Date & 2005-06 \\
\hline Doc URL & http://hdl.handle.net/2115/13784 \\
\hline Rights & Copyright $\odot 2005$ by International Solid Waste A ssociation \\
\hline Type & article (author version) \\
\hline File Information & wmr3.pdf \\
\hline
\end{tabular}

Instructions for use 


\title{
Leaching Behaviour of Elements and Evaluation of Pre-treatment Methods for Municipal Solid Waste Incinerator (MSWI) Residues in Column Leaching Tests
}

\author{
Sang-Yul Kim, Nobutoshi Tanaka, Toshihiko Matsuto, Yasumasa Tojo \\ Department of Environmental and Resource Engineering, \\ Hokkaido University, \\ Kita 13 Nishi 8, Kita-ku, Sapporo, Hokkaido, 060-8628, Japan \\ Phone: +81-11-706-6830 \\ Fax: +81-11-707-6585
}

Corresponding author: Sang-Yul, Kim

Phone: +81-11-706-6830

Fax: +81-11-707-6585

Email: sykim@eng.hokudai.ac.jp

\begin{abstract}
Two new pre-treatment methods (water-washing/carbonation and carbonation/phosphate stabilisation) of municipal solid waste (MSW) incinerator residues were evaluated by column leaching tests under aerobic conditions and anaerobic conditions (which were changed to aerobic conditions after 10 months). A mixture of bottom ash and fly ash (5:1 ratio) was pre-treated using each method. Shredded incombustible residues (SIR) were added to each ash preparation in proportions similar to the ratios present in landfills. For comparison, landfill wastes typical of Japan, i.e., a mixture of bottom ash, chelating-pre-treated fly ash, and SIR, were also examined. Leachate samples were collected periodically and analysed over a 15-month period. When compared to chelating pre-treatment, both water-washing/carbonation and carbonation/phosphate stabilisation reduced the leaching of $\mathrm{Pb}, \mathrm{Al}$, and $\mathrm{Cu}$ by about 1-2 orders of magnitude. Moreover, the initial concentrations of $\mathrm{Ca}$ and $\mathrm{Pb}$ in leachates from column of water-washing/carbonation were 56-57\% and $84-96 \%$ less than those from column of carbonation/phosphate stabilisation. Therefore, water-washing/carbonation was considered to be a promising approach to obtain early waste stabilisation and to reduce the release of heavy metals to near-negligible levels. The leaching behaviour of elements was also discussed.
\end{abstract}


KEYWORDS: MSW incinerator residues, pre-treatment, water washing, carbonation, phosphate stabilisation, heavy metals, column leaching tests, leaching behaviour

\section{Introduction}

Approximately $75 \%$ of all municipal solid waste (MSW) has been incinerated over a couple of decades in Japan. This has increased the proportion of MSW incinerator residues ending up in landfills. According to the Japanese white paper on the environment (2003), MSW incineration residues (bottom ash and fly ash) and incombustible wastes account for more than $50 \%$ of total wastes landfilled in Japan, and is expected to increase further since the location of landfill sites becomes difficult to secure.

In Japan, MSW incinerator fly ash must be pre-treated prior to its deposition in landfills, according to the Waste Disposal and Public Cleansing Law (1991). The pre-treatment options are: 1) melting and solidification; 2) solidification by cement; 3) stabilisation using chemical agents; and 4) extraction with acid or other solvents. Among these pre-treatment methods, stabilisation using chemical agents is commonly used in Japan because it is a simple and relatively inexpensive method that produces negligible volume expansion. Chelating agents, such as thiol (-SH) or dithiocarbamate (-NH-CSSH) groups, have been widely used (Tanaka 1995). In contrast to fly ash, MSW incinerator bottom ash is added directly to landfills with no legally required pre-treatment. However, it has been reported that MSW incinerator bottom ash contains 20 to 50 times larger concentrations of $\mathrm{Cd}, \mathrm{Cu}, \mathrm{Pb}$, and $\mathrm{Zn}$ than does unpolluted soil (Sakanakura 1999). In Japan, leachates from several landfills contained hazardous trace metals ( $\mathrm{Pb}, \mathrm{Cd}, \mathrm{Zn}$, $\mathrm{Cu}$, and $\mathrm{Hg}$ ) in concentrations greater than allowed by the criteria for Japanese wastewater discharge (Tanaka 2000). The location of landfill sites has become more difficult because of vastly increased public concern on the leaching of toxic heavy metals from MSW incinerator residues. In this context, the leaching of toxic heavy metals from MSW incinerator bottom ash is of growing concern in Japan.

To address this problem, previous work examined the effects of some simple and cost effective pre-treatment methods on mixtures of bottom ash and fly ash using several batch leaching tests (Kim et al. 2003). It was demonstrated that water-washing effectively removed the major elements from the mixtures of bottom ash and fly ash, and also reduced the leachability of trace metals, such as $\mathrm{Pb}$ and $\mathrm{Cd}$; carbonation significantly reduced the levels of $\mathrm{Ca}$, as well as trace metals in leachate, and phosphate stabilisation appreciably lessened the extent to which heavy metals, particularly $\mathrm{Pb}$, leached, even under acidic conditions. However, uncertainty exists on the long term availability and mobility of heavy metals retained in the landfill when atmospheric air starts to diffuse into the landfill waste during maturation phase, which causes the redox potential to raise and where sulphides may be oxidized. Therefore, it is important to understand whether 
metals continue to be immobilized within a landfill, in particular whether progressing aerobic conditions may lead to the release of heavy metals. However, relatively few such studies have been carried out on column leaching tests.

The purposes of this work were to evaluate the effectiveness of water-washing/carbonation and carbonation/phosphate stabilisation under aerobic conditions, anaerobic conditions, and changing conditions from anaerobic to aerobic conditions in column leaching experiments, and to understand the leaching characteristics of potential pollutants under such conditions.

\section{Materials and Methods}

\subsection{Materials}

Bottom ash, fly ash, chelating-pre-treated fly ash (this chelating agent included dithiocarbamates group), and shredded incombustible residues (SIR) were directly obtained from a MSW incinerator in Sapporo (Japan). SIR is defined as the residues screened by a vibrating screen after shredding bulky MSW and ferrous metal recovery by a magnetic separator. Table 1 shows the physical composition of the SIR sample. The stoker mass-burn incinerator has a processing capacity of 300 tons per day and is equipped with an electric precipitator. The flue gas is treated with injection of dry $\mathrm{Ca}(\mathrm{OH})_{2}$ prior to the electrostatic precipitators from which the fly ash was sampled from the outlet. Chelating-pre-treated fly ash and a water-quenched bottom ash were sampled separately at each ash pit, which serves as temporary storage before transfer to a landfill site. For the immobilisation of heavy metals in fly ash, $0.5 \%(\mathrm{v} / \mathrm{w})$ chelating agent and $25 \%$ $(\mathrm{w} / \mathrm{w})$ aluminium sulphate (as a coagulating agent) were applied to fly ash as a solution. After drying at $105^{\circ} \mathrm{C}$, the bottom ash that passed through a $16-\mathrm{mm}$ sieve (95\% of the total) was used. The chemical composition and ignition loss of the bottom ash and fly ash are summarized in Table 2. Prior to the pre-treatments, bottom ash and fly ash were mixed at a ratio of 5:1 on a dry weight basis (based on actual data for landfill waste in Sapporo). This ash mixture is subsequently referred to as "B-F ash."

\subsection{Methods}

\subsubsection{Pre-treatment Processing}

The processing conditions for each pre-treatment are based on previous work (Kim et al. 2003).

\section{(a) Water-washing and Carbonation (W-C)}

The B-F ash was washed with distilled water, using a liquid/solid (L/S) ratio of 5:1, and a washing time of $30 \mathrm{~min}$. After the washing process, the solids were separated from the liquid and were dried at $105^{\circ} \mathrm{C}$ for the subsequent carbonation treatment. Then $7 \mathrm{~kg}$ dry weight of the solids was set at $15 \%$ moisture content with distilled water before filled in column. An acrylic column (inner diameter $15.6 \mathrm{~cm}$, height $100 \mathrm{~cm})$ was filled with the wet $\mathrm{B}-\mathrm{F}$ ash $(15 \%$ moisture content) 
to a depth of about $40 \mathrm{~cm}$; thus the bulk density was approximately 0.92 ton $\mathrm{m}^{-3}$. Then $10 \% \mathrm{CO}_{2}$ $\left(90 \% \mathrm{~N}_{2}\right)$ gas was injected into the column from the bottom at a constant flow rate of $5 \mathrm{Lmin}^{-1}$ for $300 \mathrm{~min}$. The concentration of $\mathrm{CO}_{2}$ in the gas outlet was not detected until about $90 \mathrm{~min}$, then increased exponentially for about $240 \mathrm{~min}$, and became constant at around $9 \%$ afterwards, which was defined as the saturation of carbonation in this study. The calculated amount of $\mathrm{CO}_{2}$ absorbed by B-F ash was about $0.48 \mathrm{mmol} \mathrm{CO}_{2} \mathrm{~g}^{-1}$ dry B-F ash. If it is assumed that the total amount of $\mathrm{CO}_{2}$ adsorbed reacted with $\mathrm{Ca}(\mathrm{OH})_{2}$ in $\mathrm{B}-\mathrm{F}$ ash, the $\mathrm{CaCO}_{3}$ that would form is $0.48 \mathrm{mmol} \mathrm{CaCO}_{3}$ $\mathrm{g}^{-1}$ dry B-F ash. The pre-treated B-F ash (referred to as "W-C pre-treated B-F ash") was oven dried at $105^{\circ} \mathrm{C}$ and stored in polyethylene bags.

The W-C pre-treated B-F ash was examined by the leaching test specified in Notification No. 13 (JLT-13) of the Environment Agency of Japan (Environmental Agency, Japan 1973). W-C pre-treated B-F ash (10 g) was mixed with $100 \mathrm{~mL}$ of distilled water. The suspension was mixed for $6 \mathrm{~h}$ at room temperature and filtered through a $1-\mu \mathrm{m}$ glass fiber filter. The results are presented in Table 3. Leaching concentrations of soluble salts ( $\mathrm{Cl}, \mathrm{Na}$, and $\mathrm{K}$ ) and some trace metals $(\mathrm{Cu}, \mathrm{Pb}$, and $\mathrm{Zn})$ from $\mathrm{W}-\mathrm{C}$ pre-treated $\mathrm{B}-\mathrm{F}$ ash were lower than those of untreated $\mathrm{B}-\mathrm{F}$ ash by 73.6-84.1\% and 65.3-99.8\%, respectively. Leaching of Ca was also considerably reduced by $54.9 \%$ when compared to that of untreated B-F ash. However, there was no clear difference between the levels of $\mathrm{Cr}$ in W-C pre-treated B-F ash and in untreated B-F ash.

\section{(b) Carbonation and Phosphate Stabilisation (C-P)}

The carbonation process was the same as described above. Subsequently, the carbonated B-F ash was mixed with a phosphoric acid solution $\left(0.16 \mathrm{~mol} \mathrm{H}_{3} \mathrm{PO}_{4}\right.$ per $\mathrm{kg}$ of carbonated B-F ash) for 10 min and aged for $30 \mathrm{~min}$ in air. An $\mathrm{L} / \mathrm{S}$ ratio of 0.5 was used. The pre-treated B-F ash (referred to as "C-P pre-treated B-F ash") was dried at $105^{\circ} \mathrm{C}$ and stored in polyethylene bags. As the results of the JLT-13 leaching test, unlike the results of water-washing and carbonation (W-C) pre-treatment, C-P pre-treatment resulted in levels of soluble salts $(\mathrm{Cl}, \mathrm{Na}$, and $\mathrm{K})$ that were almost the same as levels from untreated $\mathrm{B}-\mathrm{F}$ ash; but the leaching of $\mathrm{Ca}, \mathrm{Cu}$, and $\mathrm{Pb}$ was reduced by $76 \%, 76.5 \%$, and $99.9 \%$, respectively when compared to the untreated B-F ash (Table 3 ).

\subsubsection{Column Leaching Tests}

Transparent acrylic plastic columns (inner diameter $15.6 \mathrm{~cm}$, height $1 \mathrm{~m}$ ) were filled with SIR and the B-F ash pre-treated by water-washing/carbonation or carbonation/phosphate stabilisation; these columns are subsequently referred to as "column W-C" and "column C-P", respectively. The mixture ratio of SIR to B-F ash was 1:9 on a dry weight basis, which was based on actual data for landfill waste in Sapporo. The initial water content of each sample was preset at 15\% with distilled water before packed manually in the column. Each column contained about $12 \mathrm{~kg}$ 
mixture ash of SIR and B-F ash on a dry weight basis (the bulk density of approximately 0.91-0.95 ton $\mathrm{m}^{-3}$ ). A thermostat controlled the temperature at $30^{\circ} \mathrm{C} \pm 3{ }^{\circ} \mathrm{C}$. For comparison, a mixture of bottom ash, chelating-pre-treated fly ash, and SIR was also filled in a column (referred to as "column STD") with the same ratios and conditions as for columns W-C and C-P. Column STD is prepared to simulate representative landfill wastes in Japan.

Layers of quartz-sand ( $1 \mathrm{~cm}$ deep) were placed at the top and bottom of each column to ensure a uniform feed water distribution and to prevent the formation of channels. An aerobic column and an anaerobic column were constructed for each three columns: column STD, column W-C, and column C-P (Table 4). For aerobic conditions, the top and bottom of the columns were open to air. Also, three points for gas sampling were set up at intervals of about $30 \mathrm{~cm}$ from the top of aerobic columns, in order to examine aerobic conditions in the waste mixture. The concentrations of $\mathrm{O}_{2}$ in the columns ranged from $18-21 \%$ (data not shown). For anaerobic conditions, on the other hand, gas bags were connected to the top of the anaerobic columns to measure the compositions and amount of gas generated from the waste mixture, and S-type glass pipes were connected with glass flasks at the bottom to prevent air penetration (Figure 1). Anaerobic columns were purged with $99.9 \%$ nitrogen gas after sampling for leachate and gas (every week).

During column leaching experiments, experimental conditions were altered twice, in order to examine their effects on the leaching behaviour of elements; the change in $\mathrm{pH}$ of supply water from distilled water to $\mathrm{pH} 3$ water which was adjusted with $\mathrm{HNO}_{3}$ solution at the $\mathrm{L} / \mathrm{S}$ of 1.2 , and the change of anaerobic conditions to aerobic conditions at the L/S of 2.0, by making the top and bottom of anaerobic columns open to air.

To mimic the annual average rainfall in Japan, $600 \mathrm{~mL}$ of distilled water was fed onto each column once every week, which is equivalent to an L/S of 0.05 per week; the leachate was sampled twice: $12 \mathrm{~h}$ after a feeding and just prior to the next feeding. Only small differences in the concentrations of elements were found between the two separately collected leachate samples, so the data presented here are from the first sample ( $12 \mathrm{~h}$ leachate). Leachate was collected and analysed over the 15-month period. In column leaching experiments, L (1) refers to the accumulated amount of collected leachate and S $(\mathrm{kg})$ is the dry weight of B-F ash and SIR in the column.

\subsubsection{Geochemical Modeling}

The computer program MINTEQA2 version 3.11 (Allison et al. 1991) was used to interpret the leaching behaviour of heavy metals from all columns. Input files in MINTEQA2 program contain total concentrations of inorganic elements measured in leachates as well as the $\mathrm{pH}$ and ionic strength, which was fixed at the measured value. No solids were allowed to precipitate. Potential solubility-controlling minerals were selected on the basis of (1) the likeliness of their presence or 
formation under the experimental conditions, and/or (2) saturation indices (SI), and/or (3) model-predicted curve shapes that follow the thermodynamic log activities of heavy metals of interest versus $\mathrm{pH}$ graphs. The thermodynamic log activities of heavy metals were calculated from analytical total concentrations using MINTEQA2, taking into account the ionic strength for each sample.

\subsubsection{Analytical Methods}

Heavy metals in acidified filtrates $(<\mathrm{pH} 2)$ were analysed by GF-AAS (Hitachi Z-8200) or flame AAS (Hitachi 170-50A and/or Hitachi A-2000). The concentrations of $\mathrm{Cl}^{-}$were determined by ion chromatography (TOSOH CM-8). Biological oxygen demand for 5 days $\left(\mathrm{BOD}_{5}\right)$ was determined by the methods of the Japan Society for Analytical Chemistry (JSAC, 1994). The pH and Eh (redox potential) of aqueous samples were determined with a glass electrode (HORIBA D-24).

\section{Results and Discussion}

\section{$3.1 \mathrm{pH}$}

Figure 2 shows the $\mathrm{pH}$ of leachates as functions of $\mathrm{L} / \mathrm{S}$ ratios. The leachate $\mathrm{pH}$ values in all columns were established early and did not change substantially with L/S ratios, even after the feeding of acidic water ( $\mathrm{pH} 3)$.

In column STD, leachate $\mathrm{pH}$ values were very high $(\mathrm{pH}$ 11.9-12.4) because of the presence of $\mathrm{Ca}(\mathrm{OH})_{2}$ and alkali metal hydroxides. The gap between the $\mathrm{pH}$ values under aerobic versus anaerobic conditions in column STD became larger with increasing L/S ratios (or time), which seemed to be higher $\mathrm{CO}_{2}$ concentrations under aerobic conditions than under anaerobic conditions. Column STD under aerobic conditions was always open to atmospheric $\mathrm{CO}_{2}$, while the amount of $\mathrm{CO}_{2}$ gas produced by microbial activities was considered to be negligible under anaerobic conditions at high $\mathrm{pH}$. In columns W-C and C-P, on the other hand, the $\mathrm{pH}$ values under aerobic conditions remained near 8.2, except in the initial stage. However, in the case of anaerobic conditions in column $\mathrm{W}-\mathrm{C}$, the $\mathrm{pH}$ values stayed at 9-9.5 until the $\mathrm{L} / \mathrm{S}$ reached 2.0; at that point, the anaerobic conditions were replaced by aerobic conditions and the $\mathrm{pH}$ of the leachate dropped to 8.1-8.3. This lower $\mathrm{pH}$ values are considered due to carbonation through the interaction between atmospheric $\mathrm{CO}_{2}$ and calcium ion in leachate. This will be discussed later (see to 3.2).

If it is assumed that the buffering of leachate solutions primarily is by calcite $\left(\mathrm{CaCO}_{3}\right)$ (Meima \& Comans 1997; Johnson \& Furrer 2002), it would take approximately 9500 years until the entire stock of calcite was used up. The rough estimation was carried out as follows: Assuming that fifty percent of Japanese average annual rainfall $(1,600 \mathrm{~mm})$ infiltrate the leachate production will be $0.8 \mathrm{~m}^{3} \mathrm{~m}^{-2}$ year $^{-1}$ ). The solubility of $\mathrm{CaCO}_{3}$ at $\mathrm{pH} 8.3$ corresponds to about $25 \mathrm{mgL}^{-1} \mathrm{Ca}$ at 
ambient partial pressure of $\mathrm{CO}_{2}$. Therefore, the amount of wash out of Ca becomes $20 \mathrm{~g}$ year ${ }^{-1}$. Meanwhile, about $0.48 \mathrm{~mol} \mathrm{~kg}^{-1}$ of $\mathrm{CaCO}_{3}$ in dry B-F ash (see to 2.2 .1 (a)) corresponds to $190 \mathrm{~kg}$ $\mathrm{Ca}$ in a landfill of $10 \mathrm{~m}$ depth $\left(10 \mathrm{~m}^{3} \approx 10\right.$ ton $\mathrm{B}-\mathrm{F}$ ash). The buffer lifetime of B-F ash amounts theoretically to about 9500 years. It should be noted that this calculation assumes ambient partial pressure of $\mathrm{CO}_{2}$. The buffer lifetime would be shorter if the $\mathrm{CO}_{2}$ produced by biodegradation is considered. However, the organic content in bottom ash is not high enough to significantly alter the buffer lifetime of B-F ash.

\subsection{Ca}

Although the leachate $\mathrm{pH}$ was nearly the same, the concentrations of $\mathrm{Ca}$ in the first leachate sampled from the W-C column were 56-57\% less than those from the C-P column (Fig. 3(a)). According to a previous study (Kim et al. 2003), this discrepancy was produced by the water-washing pre-treatment, which can remove some soluble species such as gypsum $\left(\mathrm{CaSO}_{4}\right)$, $\mathrm{CaCl}_{2}, \mathrm{CaO}$, and $\mathrm{Ca}(\mathrm{OH})_{2}$, from MSWI ash. The calculated $\mathrm{Ca}^{2+}$ activities in column STD were similar to those predicted from $\mathrm{Ca}(\mathrm{OH})_{2}$ in both aerobic and anaerobic conditions (Fig. 3(b)), suggesting that they were controlled primarily by $\mathrm{Ca}(\mathrm{OH})_{2}$. However, the $\mathrm{Ca}^{2+}$ activities deviated from those predicted from $\mathrm{Ca}(\mathrm{OH})_{2}$ during the latter part of aerobic conditions and after the change from anaerobic to aerobic conditions (see to arrows in Fig. 3(b)), indicating that carbonation occurred slowly through the interaction with atmospheric $\mathrm{CO}_{2}$. On the other hand, in the case of columns W-C and C-P, the $\mathrm{Ca}^{2+}$ activities followed those predicted from $\mathrm{CaCO}_{3} \mathrm{xH}_{2} \mathrm{O}$ under aerobic conditions, while the $\mathrm{Ca}^{2+}$ activities under anaerobic conditions were above those predicted from $\mathrm{CaCO}_{3} \times \mathrm{H}_{2} \mathrm{O}$ and then approached the activity line of $\mathrm{CaCO}_{3} \mathrm{xH}_{2} \mathrm{O}$ during the latter part of aerobic conditions and after the change from anaerobic to aerobic conditions (see to arrows in Fig 3(b)). These results suggested that the lack of $\mathrm{CO}_{2}$ gas under anaerobic conditions caused $\mathrm{CaCO}_{3} \mathrm{XH}_{2} \mathrm{O}$ precipitates to form slowly.

\section{$3.3 \mathrm{Al}$}

Figure 4(a) shows that the leaching of Al in column STD increased to $34-45 \mathrm{mg} \mathrm{L}^{-1}$, with $\mathrm{L} / \mathrm{S}$ ratios, while the concentrations of $\mathrm{Al}$ in columns W-C and C-P decreased until an L/S of about 0.8 , and levelled out at 1-3 $\mathrm{mg} \mathrm{L}^{-1}$ afterwards, except for those under anaerobic conditions in column W-C. The calculated $\mathrm{Al}^{3+}$ activities in highly alkaline leachate (column STD) were similar to those in equilibrium with crystalline $\mathrm{Al}(\mathrm{OH})_{3}$ (gibbsite) (Figure 4(b)), suggesting that $\mathrm{Al}$ concentrations in column STD were controlled by crystalline $\mathrm{Al}(\mathrm{OH})_{3}$. On the other hand, the calculated $\mathrm{Al}^{3+}$ activities in columns W-C and C-P were similar to those in equilibrium with amorphous $\mathrm{Al}(\mathrm{OH})_{3}$, suggesting that $\mathrm{Al}$ concentrations in columns $\mathrm{W}-\mathrm{C}$ and $\mathrm{C}-\mathrm{P}$ were controlled by amorphous $\mathrm{Al}(\mathrm{OH})_{3}$. Similar results were reported by Fruchter et al. (1990)

\section{4 $\mathrm{Cu}$ and $\mathrm{Pb}$}

As shown in Figure 5(a), the concentrations of $\mathrm{Cu}$ under aerobic conditions in column STD 
constantly decreased from 21.7 to $1.8 \mathrm{mg} \mathrm{L}^{-1}$ with $\mathrm{L} / \mathrm{S}$ ratios, which seemed to show little effect of chelating-pre-treatment from the beginning. On the other hand, under anaerobic conditions in column STD, leachate $\mathrm{Cu}$ decreased about 1-2 orders of magnitude less than those under aerobic conditions until the L/S reached 0.8 (at about 5 months). According to the results of the JLT-13 test (Table 3), bottom ash has more soluble $\mathrm{Cu}$ than fly ash $\left(2.12 \mathrm{mg} \mathrm{L}^{-1} \mathrm{Cu}\right.$ for bottom ash and $0.15 \mathrm{mg} \mathrm{L}^{-1} \mathrm{Cu}$ for fly ash). And that of the chelating-pre-treated fly ash was less than $0.01 \mathrm{mg}$ $\mathrm{L}^{-1}$ (data not shown). Furthermore, considering large amount of bottom ash in columns (5 times larger than fly ash on a dry weight basis), most $\mathrm{Cu}$ are considered to be released from bottom ash. Therefore, it is difficult to explain a sharp decrease (until the L/S reached 0.8) under anaerobic conditions with only small portion of the chelating-pre-treated fly ash. One plausible explanation is that surplus chelating agents dissolved from the chelating-pre-treated fly ash may react slowly with the $\mathrm{Cu}$ leached from bottom ash under anaerobic conditions. After that, $\mathrm{Cu}$ sharply increased from 0.95 to $3.6 \mathrm{mg} \mathrm{L}^{-1}$ at an $\mathrm{L} / \mathrm{S}$ of 0.8 and then decreased again. The sudden increase of $\mathrm{Cu}$ (from 1.17 to $3.67 \mathrm{mg} \mathrm{L}^{-1}$ ) was observed after the change from anaerobic to aerobic conditions. Similar leaching behaviour was observed for Pb in column STD and is discussed later. In columns W-C and C-P, on the other hand, the leaching concentrations of $\mathrm{Cu}$ decreased about 1-2 orders of magnitude less than those in column STD.

The concentrations of $\mathrm{Pb}$ under aerobic conditions in column STD decreased from 4.63 to 0.02 $\mathrm{mg} \mathrm{L}^{-1}$ with increasing $\mathrm{L} / \mathrm{S}$ ratios (or time). On the other hand, under anaerobic conditions in column $\mathrm{STD}$, the leaching behaviour of $\mathrm{Pb}$ had two patterns, as already observed for $\mathrm{Cu}$ : leachate $\mathrm{Pb}$ decreased from 4.27 to $0.3 \mathrm{mg} \mathrm{L}^{-1}$ until the $\mathrm{L} / \mathrm{S}$ reached 0.8 (at about 5 months), and increased from 0.3 to $1.92 \mathrm{mg} \mathrm{L}^{-1}$ at an L/S of 0.8 and increased once again from 0.93 to $3.18 \mathrm{mg} \mathrm{L}^{-1}$ after the change from anaerobic to aerobic conditions (Figure 5(b)). Considering the characteristics of chelating agents, which have higher affinities for $\mathrm{Cu}$ and $\mathrm{Pb}$ than for the other elements (Sakanakura 1999), insoluble chelating complexes with $\mathrm{Cu}$ and $\mathrm{Pb}$ seemed to break up at an $\mathrm{L} / \mathrm{S}$ of 0.8 under anaerobic conditions for some unknown reason (e.g. unexpected infiltration of $\mathrm{O}_{2}$ during sampling). Several reports on the re-release of metals immobilized in chelating-pre-treated fly ash have appeared in Japan (Kamiishi \& Takahashi 1988; Noma et al. 1989; Yuki et al. 1997; Sakanakura 1999). Sakanakura (1999) indicated that interactions with air and water evaporation are the crucial causes to weaken the bonding capacity of chelating agents.

On the other hand, the leaching of $\mathrm{Pb}$ from columns W-C and C-P decreased to $0.002 \mathrm{mg} \mathrm{L}^{-1}$ at an $\mathrm{L} / \mathrm{S}$ of about 0.5 and stayed less than the detection limit $\left(0.002 \mathrm{mg} \mathrm{L}^{-1}\right)$ throughout the experimental period. Furthermore, the initial concentration of $\mathrm{Pb}$ from column $\mathrm{W}-\mathrm{C}$ was 84-96 \% less than that from column C-P, probably because of the water-washing pre-treatment, as observed for $\mathrm{Ca}$. The effect of water-washing pre-treatment on $\mathrm{Pb}$ suggested that water-washing may not only remove readily soluble $\mathrm{Pb}$ species but may also reduce the leaching of $\mathrm{Pb}$ by 
removing a significant amount of $\mathrm{Cl}$, thereby precluding the formation of $\mathrm{Cl}$ complexes of $\mathrm{Pb}$, which would have been more soluble (Cernuschi et al. 1990; Kim et al. 2002).

\section{$3.5 \mathrm{Cr}$}

The leachate concentrations of $\mathrm{Cr}$ for all columns exhibited significantly different behaviour depending on aerobic or anaerobic conditions, but they seemed to be little affected by pre-treatment methods (Fig 6). Cr concentrations under aerobic conditions were constant (about 0.01-0.06 $\mathrm{mg} \mathrm{L}^{-1} \mathrm{Cr}$ ), whereas $\mathrm{Cr}$ concentrations under anaerobic conditions decreased to the detection limit $\left(0.001 \mathrm{mg} \mathrm{L}^{-1} \mathrm{Cr}\right)$ within an $\mathrm{L} / \mathrm{S}$ of 0.5 and were not detected until an $\mathrm{L} / \mathrm{S}$ of 2.0 , and increased more than 1-2 orders of magnitude (about $0.01-0.1 \mathrm{mg} \mathrm{L}^{-1} \mathrm{Cr}$ ) upon changing to aerobic conditions.

These findings suggested that chromates formed during incineration would be slowly reduced under anaerobic conditions and release again when the aerobic phase set in. The Eh-pH diagram for $\mathrm{CrO}_{4}{ }^{2-} / \mathrm{Cr}_{2} \mathrm{O}_{3}$ showed the valence change of $\mathrm{Cr}$ depending on aerobic or anaerobic conditions (data not shown).

\section{Conclusions}

In this study, two new alternative pre-treatments (water-washing/carbonation and carbonation/phosphate stabilisation) for MSW incinerator residues were examined using column leaching tests and were compared with a conventional chelating agent pre-treatment method. The following conclusions were obtained:

Compared to a conventional chelating agent pre-treatment (column STD), both water-washing/carbonation (column W-C) and carbonation/phosphate stabilisation (column C-P) pre-treatments reduced the leachability of $\mathrm{Al}, \mathrm{Cu}$, and $\mathrm{Pb}$ by about 1-2 orders of magnitude. In particular, the initial concentrations of $\mathrm{Ca}$ and $\mathrm{Pb}$ in leachate from the column of water-washing/carbonation were $56-57 \%$ and $84-96 \%$ less than those from the column of carbonation/phosphate stabilisation, although the leachate $\mathrm{pHs}$ were nearly the same, which is probably due to the effects of the water-washing pre-treatment. For columns W-C and C-P, carbonation played a significant role in neutralizing MSWI residues, resulting in very low solubility of most trace metals in the leachate.

Of the two new methods, water-washing/carbonation would be better than carbonation/phosphate stabilisation because of the significant reduction of initial concentrations of some trace metals and soluble salts as well as the strong buffering capacity of B-F ash (about 9500 years until the depletion of $\mathrm{CaCO}_{3}$ ). Therefore, water-washing/carbonation was considered as promising approach to obtain earlier waste stabilisation and to reduce the release of heavy metals to near-negligible levels.

In terms of leaching characteristics of the elements in the leachate, most compounds in the fly 
ash/bottom ash mixtures were qualitatively interpreted with $\mathrm{pH}$, time, $\mathrm{O}_{2}$, and $\mathrm{CO}_{2}$ conditions. It was found that the leaching of $\mathrm{Ca}$ was controlled primarily by $\mathrm{CaCO}_{3} \mathrm{xH}_{2} \mathrm{O}(\mathrm{pH}$ 7.13-9.57) and $\mathrm{Ca}(\mathrm{OH})_{2}(\mathrm{pH} 11.7-12.8)$, respectively. It was also found that $\mathrm{CO}_{2}$ was the important factor affecting leaching behaviour of $\mathrm{Ca}$. Carbonation through the interaction with $\mathrm{CO}_{2}$ gas tended to occur slowly. The leaching of $\mathrm{Al}$ was controlled primarily by amorphous $\mathrm{Al}(\mathrm{OH})_{3}(\mathrm{pH} 7.13-9.57)$ or crystalline $\mathrm{Al}(\mathrm{OH})_{3}(\mathrm{pH} 11.7-12.8)$, respectively. It is noted that a late mobilisation of $\mathrm{Pb}$ and $\mathrm{Cu}$ was observed in chelating-pre-treated fly ash (dithiocarbamate group). For $\mathrm{Cr}$, atmospheric $\mathrm{O}_{2}$ was the decisive factor affecting leaching behaviour. Significantly less $\mathrm{Cr}$ leached from columns under anaerobic conditions because of the reduction of $\mathrm{Cr}$. Therefore, careful attention should be given to $\mathrm{Cr}(\mathrm{VI})$ which was highly mobile under aerobic conditions and after the change from anaerobic to aerobic conditions. 


\section{Reference}

1. Abbas, Z., Steenari, B.M., \& Lindqvist, O. (2001) A study of Cr(VI) in ashes from fluidized bed combustion of municipal solid waste: leaching, secondary reactions and the applicability of some speciation methods. Waste Management 21, 725-739.

2. Allison, J.D., Brown, D.S. \& Novo-Gradac, K.J. MINTEQA2/PRODEFA2, A geochemical assessment model for environmental systems: Version 3.0 User's manual; Environmental Research Laboratory, U.S.EPA: Athens, GA, 1991.

3. Cernuschi, S., Giugliano, M. \& De Poli, I. (1990) Leaching of residues from MSW Incineration. Waste Management \& Research 8, 419-427.

4. Environment Agency, Japan, Testing methods for metals in industrial wastes, Notification No. 13 of the Environment Agency, February 17, 1973, in Japanese

5. Fruchter, J.S., Rai, D. \& Zachara, J.M. (1990) Identification of solubility-controlling solid phases in a large fly ash field lysimeter. Environmental Science \& Technology 24 (8), 1173-1179 6. Johnson, C.A. \& Furrer, G. (2002) Influence of biodegradation processes on the duration of $\mathrm{CaCO}_{3}$ as a $\mathrm{pH}$ buffer in municipal solid waste incinerator bottom ash. Environmental Science \& Technology 36, 215-220.

7. JSAC (1994) Water Analysis $4^{\text {th }}$ edition, The Japan Society for Analytical Chemistry, Hokkaido branch, Japan (in Japanese).

8. Kamiishi, H. \& Takahashi, T. (1998) Stabilisation of chelating-pre-treated fly ash (in Japanese). Proceedings of the $9^{\text {th }}$ annual conference of the Japan Society of Waste Management Experts, 791-793.

9. Kim, S.Y., Matsuto, T. \& Tanaka, N (2002) Solubility and adsorption characteristics of Pb in leachate from MSW incinerator bottom ash. Waste Management \& Research 20 (4), 373-381. 10. Kim, S.Y., Matsuto, T. \& Tanaka, N (2003) Evaluation of pre-treatment methods for landfill disposal of residues from municipal solid waste incineration. Waste Management \& Research 21 (5), 416-423.

11. Marani, D., Macchi, G. \& Pagano, M. (1995) Lead precipitation in the presence of sulphate and carbonate: Testing of thermodynamic predictions. Water Research 29(4), 1085-1092.

12. Meima, J.A. \& Comans, R.N.J. (1997) Geochemical modelling of weathering reaction in municipal solid waste incinerator bottom ash. Environmental Science and Technology 31, 1269-1276.

13. Ministry of the Environment, Japanese White Paper on the Environment 2003.

14. Noma, Y., Kita, A., Takanobe, K. \& Kodama, M. (1989) Long term stability of EP fly ash with chelating agent (in Japanese). Proceedings of the $1^{\text {st }}$ annual conference of the Japan Society of Waste Management experts, 173-176.

15. Sakanakura, H. (1999) Study on stabilisation of heavy metal in municipal solid waste 
incinerator residues by chelating agents (in Japanese). $\mathrm{PhD}$ thesis pp 2 \& 45-48

16. Tanaka N. (2000) Construction and management of MSW landfill. $1^{\text {st }}$ edition. Gihoudo publication. Japan, 137-138.

17. Tanaka Y. (1995) Recent performance on the treatment of heavy metals by chelating methods (in Japanese). Sangyo to Kankyo 24(9), 77-79.

18 Wagman, D.D., Evans, W.H., Parker, V.B., Halow, I., Bailey, S.M. \& Schumm, R.H. (1968)

Selected values of chemical thermodynamic properties. NBC Technical Note 270-273.

19 Weast, R.C. (1987) Handbook of Chemistry and Physics, $68^{\text {th }}$ edition. CRC Press, Cleveland, Ohio.

20. Yuki, O., Kawaguchi, S., Ohno, K., Moriyama, N. \& Urushiyama, E. (1997) Long term stability of chelating-pre-treated fly ash in column leaching tests (in Japanese). Journal of Japan waste management association 50 (217), 134-137 
Table 1. The physical composition of shredded incombustible residues (SIR) used in this study

\begin{tabular}{cc}
\hline Component & \% (weight) \\
\hline Glass & 34.4 \\
Stone & 28.6 \\
Plastics & 21.5 \\
Metals & 5.3 \\
Paper \& Wood & 4.1 \\
Others (i.e. soil) & 6.2 \\
Total & 100.0 \\
\hline
\end{tabular}


Table 2. Properties of the bottom and fly ash used in this study

\begin{tabular}{|c|c|c|c|}
\hline \multirow[b]{2}{*}{ Element } & \multicolumn{2}{|c|}{ Concentration $^{1)}$} & \multirow[b]{2}{*}{ Method } \\
\hline & Bottom ash & Fly ash & \\
\hline $\mathrm{Al}(\%)$ & 5.4 & 5.0 & FAAS \\
\hline $\mathrm{Ca}(\%)$ & 10.1 & 12.8 & FAAS \\
\hline $\mathrm{Cl}(\%)$ & 0.89 & 12.4 & IC \\
\hline $\mathrm{Fe}(\%)$ & 2.5 & 0.7 & FAAS \\
\hline K (\%) & 1.2 & 4.1 & FAAS \\
\hline $\mathrm{Na}(\%)$ & 1.6 & 5.1 & FAAS \\
\hline Si (\%) & 14.5 & 8.2 & $\mathrm{HF}^{2)} /$ FAAS \\
\hline $\mathrm{Cd}\left(\mathrm{mg} \mathrm{kg}{ }^{-1}\right)$ & 3.2 & 102 & GF-AAS \\
\hline $\mathrm{Cu}\left(\mathrm{mg} \mathrm{kg}^{-1}\right)$ & 9700 & 1130 & GF-AAS \\
\hline $\mathrm{Cr}\left(\mathrm{mg} \mathrm{kg}^{-1}\right)$ & 208 & 126 & GF-AAS \\
\hline $\operatorname{Mg}\left(\mathrm{mg} \mathrm{kg}^{-1}\right)$ & 8350 & 10300 & GF-AAS \\
\hline $\operatorname{Mn}\left(\mathrm{mg} \mathrm{kg}^{-1}\right)$ & 547 & 430 & GF-AAS \\
\hline $\mathrm{Pb}\left(\mathrm{mg} \mathrm{kg}^{-1}\right)$ & 1240 & 2810 & GF-AAS \\
\hline $\mathrm{Zn}\left(\mathrm{mg} \mathrm{kg}{ }^{-1}\right)$ & 2290 & 8100 & GF-AAS \\
\hline Ignition loss $^{3)}(\%)$ & 7.7 & 3.9 & \\
\hline
\end{tabular}

${ }^{1)} \mathrm{HNO}_{3} / \mathrm{HCl}$ total digestion except for $\mathrm{Si},{ }^{2)} \mathrm{HF}$ digestion, and ${ }^{3)}$ Ignition loss: $600^{\circ} \mathrm{C}$ for $3 \mathrm{hr}$ FAAS: flame atomic absorption spectroscopy

GF-AAS: Graphite furnace AAS, IC: ion chromatography 
Table 3. Concentrations of elements and $\mathrm{pH}$ in the leachate after JLT-13 test (unit $\mathrm{mg} \mathrm{L}^{-1}$,except for $\mathrm{pH}$ )

\begin{tabular}{|c|c|c|c|c|c|c|c|}
\hline & Bottom ash & Fly ash & STD B-F ash ${ }^{1)}$ & Untreated B-F ash & $\begin{array}{c}\text { W-C pretreated } \\
\text { B-F ash }\end{array}$ & $\begin{array}{c}\text { C-P pretreated } \\
\text { B-F ash }\end{array}$ & $\begin{array}{l}\text { I Detection } \\
\text { limit }\end{array}$ \\
\hline $\mathrm{pH}$ & 12.4 & 12.5 & 12.3 & 12.4 & 10.36 & 9.64 & \\
\hline $\mathrm{Ca}$ & 510 & 2663 & 905 & 921 & 415 & 221 & 1 \\
\hline $\mathrm{Cd}$ & NA & 0.004 & 0.0006 & $\mathrm{ND}^{2)}$ & ND & 0.0005 & 0.0005 \\
\hline $\mathrm{Cl}$ & 520 & 10480 & 2147 & 2002 & 528 & 2031 & 5 \\
\hline $\mathrm{Cr}$ & 0.004 & 0.018 & 0.014 & 0.006 & 0.016 & 0.007 & 0.001 \\
\hline $\mathrm{Cu}$ & 2.12 & 0.15 & 1.33 & 1.79 & 0.62 & 0.42 & 0.1 \\
\hline K & 110 & 3453 & 560 & 668 & 116 & 643 & 0.1 \\
\hline $\mathrm{Na}$ & 250 & 3598 & 538 & 736 & 117 & 556 & 0.1 \\
\hline $\mathrm{Pb}$ & 1.56 & 58.26 & 1.17 & 4.66 & 0.008 & 0.003 & 0.002 \\
\hline $\mathrm{Zn}$ & 1.84 & 2.29 & 1.40 & 3.31 & ND & ND & 0.2 \\
\hline
\end{tabular}

1) STD B-F ash means "standard mixture ash" which based on actual rate of bottom ash and chelating-pretreated fly ash (5:1 ratio) for landfill waste in Sapporo.

${ }^{2)}$ ND means "less than the detection limit" 
Table 4. Experimental conditions for each column

\begin{tabular}{|c|c|c|c|}
\hline Condition & Column STD & Column W-C & Column C-P \\
\hline $\begin{array}{l}\text { Pre-treatment } \\
\text { method }\end{array}$ & $\begin{array}{l}\text { Chelating } \\
\text { pretreatment }\end{array}$ & $\begin{array}{l}\text { Water washing } \\
\text { /Carbonation }\end{array}$ & $\begin{array}{l}\text { Carbonation/Phosphate } \\
\text { Stabilization }\end{array}$ \\
\hline Pre-treated Material & Fly ash & $\begin{array}{l}\mathrm{B}-\mathrm{F}^{1)} \text { ash } \\
(5: 1 \text { ratio })\end{array}$ & B-F ash (5:1 ratio) \\
\hline Mass of waste mixture & \multicolumn{3}{|c|}{$\begin{array}{l}12 \mathrm{~kg} \text { on a dry weight basis } \\
\text { (Bottom ash } 75 \mathrm{wt} \% \text {, Fly ash } 15 \mathrm{wt} \% \text {, and } \mathrm{SIR}^{2)} 10 \mathrm{wt} \% \text { ) }\end{array}$} \\
\hline Bulk density & \multicolumn{3}{|c|}{$0.91-0.95$ ton $\mathrm{m}^{-3}$} \\
\hline L/S ratios (periods) & \multicolumn{3}{|c|}{ L/S of 3 (15 months) } \\
\hline $\begin{array}{l}\mathrm{pH} \text { conditions of } \\
\text { artificial rain } \\
\text { (distilled water) }\end{array}$ & \multicolumn{3}{|c|}{$\begin{array}{l}\text { No control (until L/S of } 1.2 \text { ) } \\
\text { pH } 3 \text { water from L/S of } 1.2 \text { to } 3\end{array}$} \\
\hline Initial water content & \multicolumn{3}{|c|}{$15 \%$} \\
\hline Temperature & \multicolumn{3}{|c|}{$30 \pm 3{ }^{\circ} \mathrm{C}$} \\
\hline
\end{tabular}

Aerobic conditions and Anaerobic conditions*

1) B-F ash means a mixture of bottom and fly ash

2) SIR stands for Shredded Incombustible Residues

*After 10 months (L/S 2) anaerobic columns were changed to aerobic columns by making them open to air 


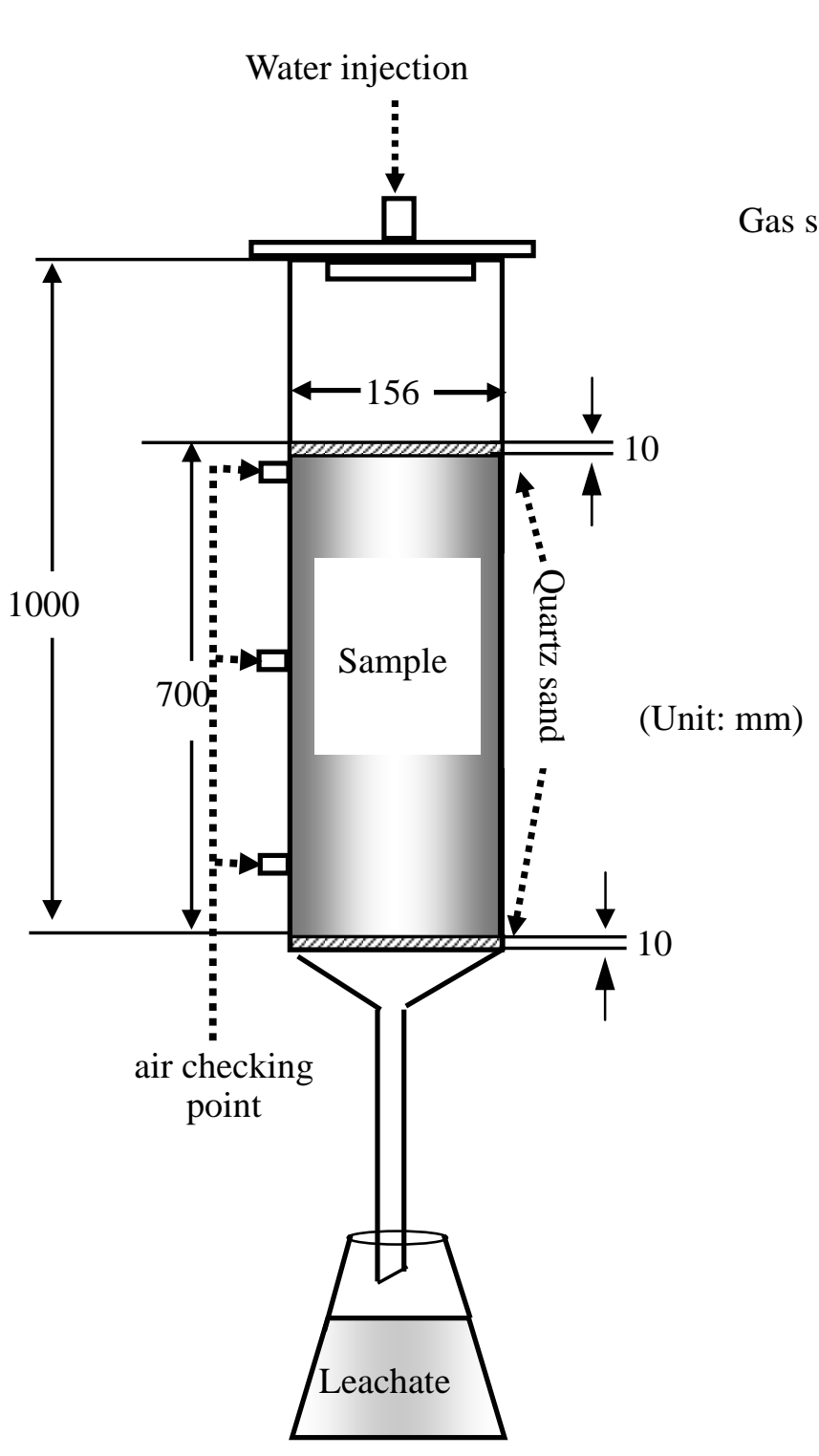

Aerobic condition

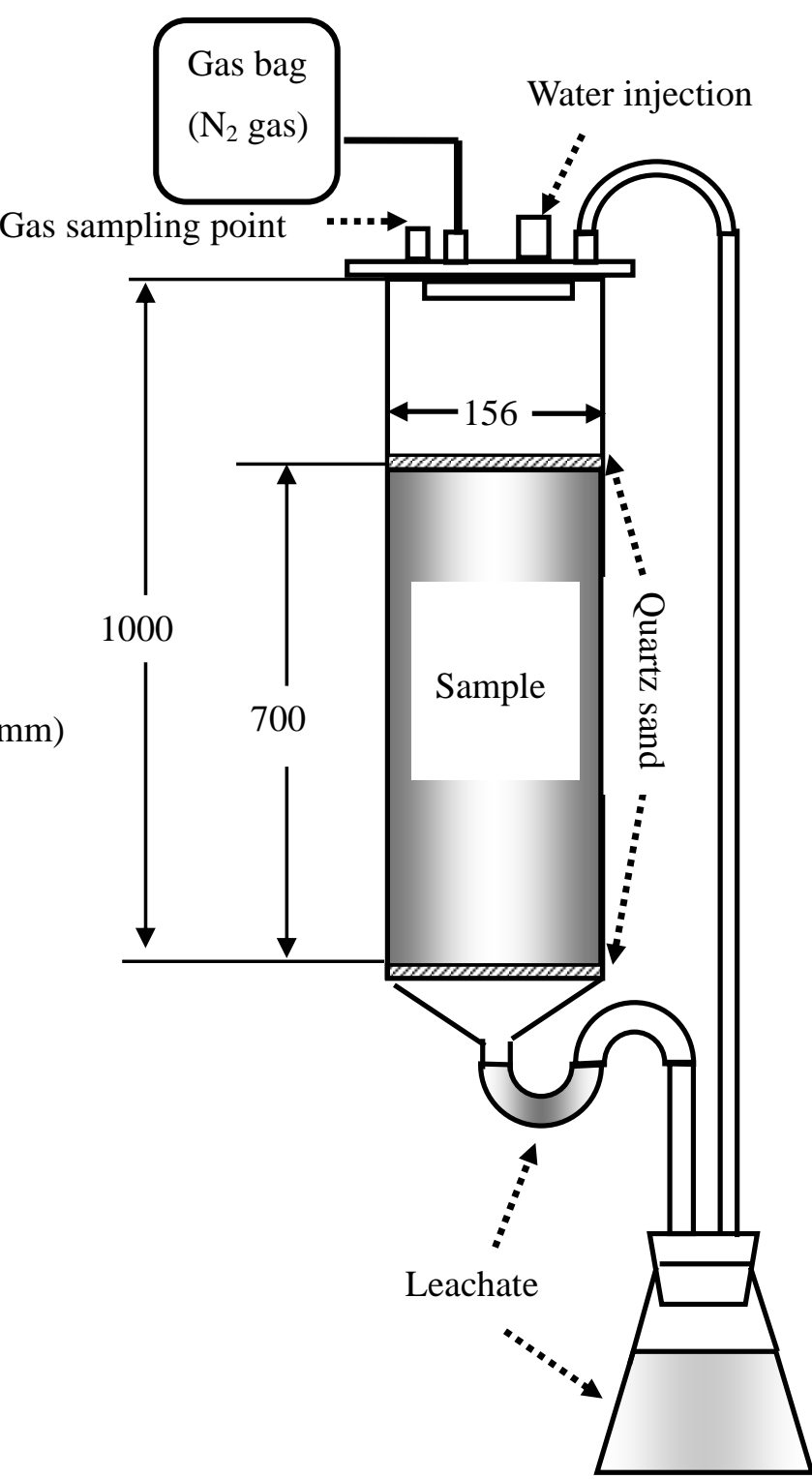

Anaerobic condition

Fig. 1 Set-up for column leaching experiments under semi-aerobic and anaerobic conditions 


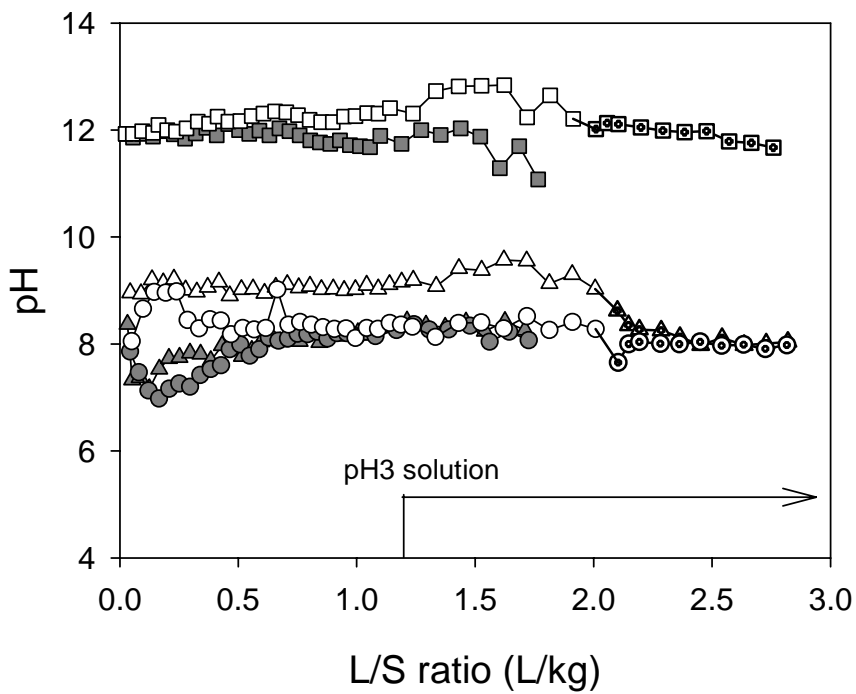

Aerobic column STD

$\Delta$ Aerobic column W-C

- Aerobic column C-P

口 Anaerobic column STD

$\triangle$ Anaerobic column W-C

- Anaerobic column C-P

a Changed to aerobic column STD

A Changed to aerobic column W-C

- Changed to aerobic column C-P

Fig. 2 Leachate $\mathrm{pH}$ and redox potential (Eh) versus L/S ratio for each column 


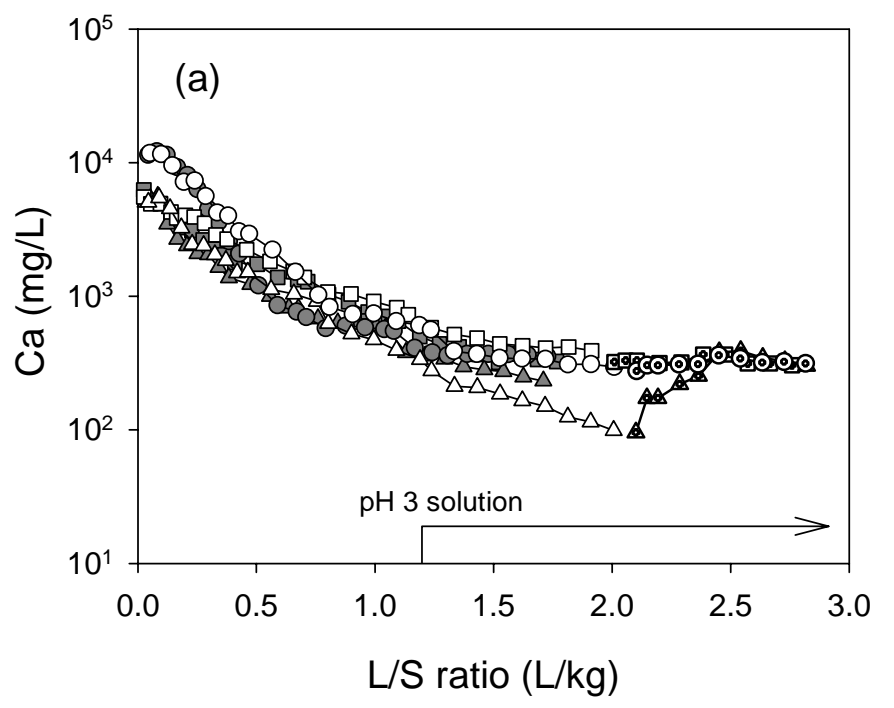

- Aerobic column STD

$\Delta$ Aerobic column W-C

- Aerobic column C-P

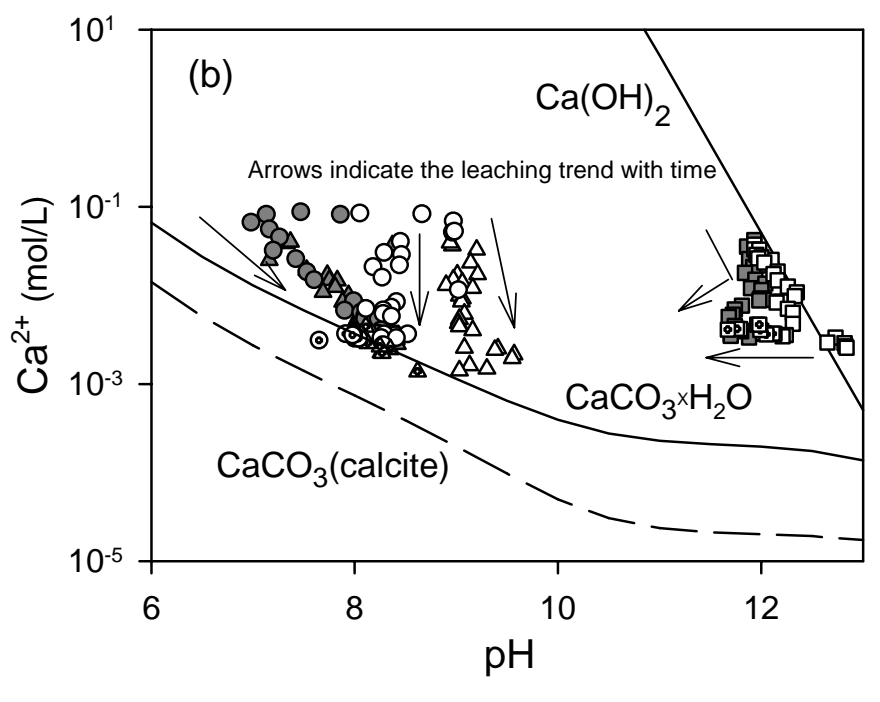

Changed to aerobic column STD

^ Changed to aerobic column W-C

- Changed to aerobic column C-P

Fig. 3 Concentrations of $\mathrm{Ca}$ as functions of $\mathrm{L} / \mathrm{S}$ ratio, and plot of calculated $\mathrm{Ca}^{2+}$ activities for various leachates, compared to activities predicted from $\mathrm{Ca}(\mathrm{OH})_{2}, \mathrm{CaCO}_{3}$, and $\mathrm{CaCO}_{3} \mathrm{xH}_{2} \mathrm{O}$ at total inorganic carbon $=10 \mathrm{mg} / \mathrm{L}$. 


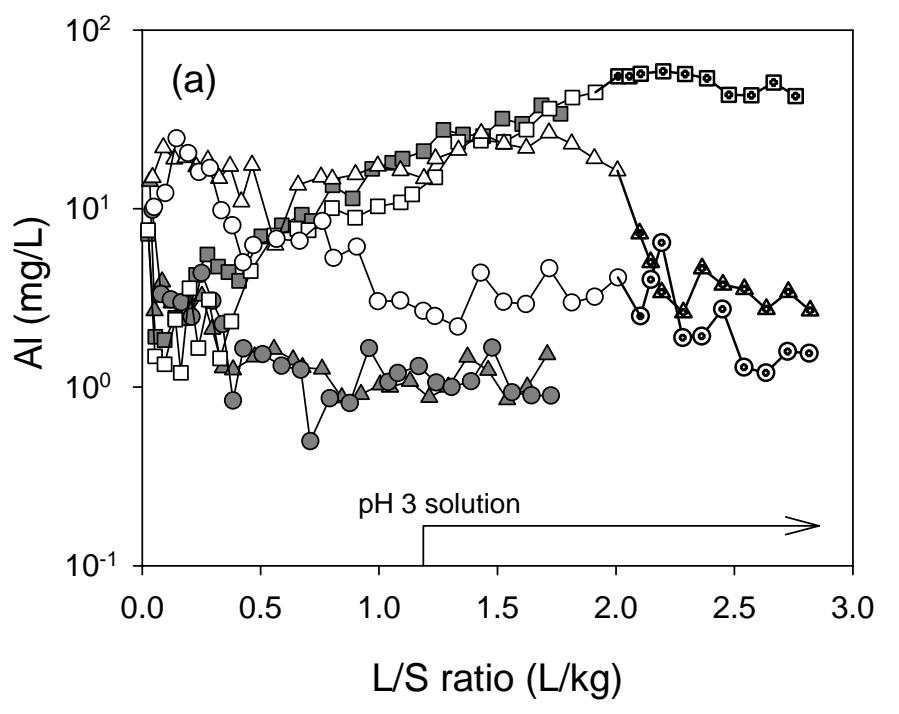

Aerobic column STD

$\triangle$ Aerobic column W-C

- Aerobic column C-P

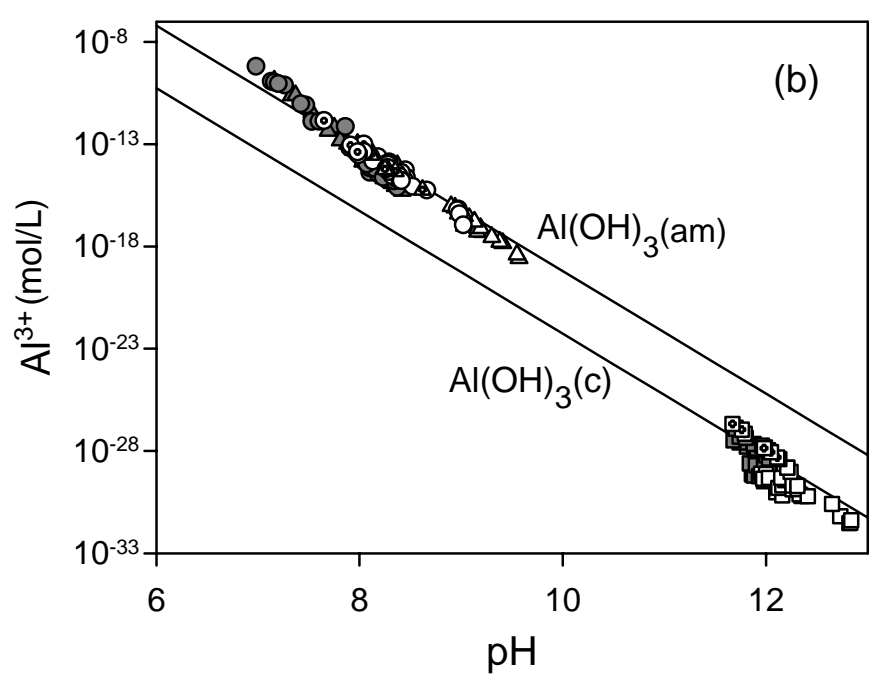

घ Changed to aerobic column STD

$\triangle$ Changed to aerobic column W-C

- Changed to aerobic column C-P

Fig. 4 Concentrations of $\mathrm{Al}$ as functions of $\mathrm{L} / \mathrm{S}$ ratio, and plot of calculated $\mathrm{Al}^{3+}$ activities for various leachates, compared to activities predicted from amorphous $\mathrm{Al}(\mathrm{OH})_{3}$ and crystalline $\mathrm{Al}(\mathrm{OH})_{3}$ (gibbsite) 


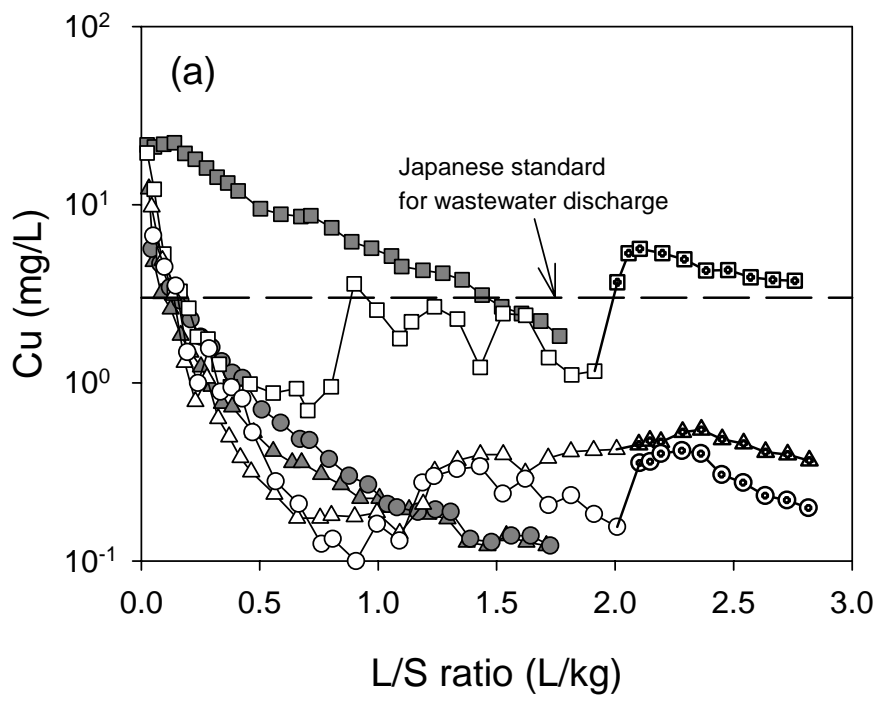

Aerobic column STD

Anaerobic column STD

$\triangle$ Aerobic column W-C

- Aerobic column C-P

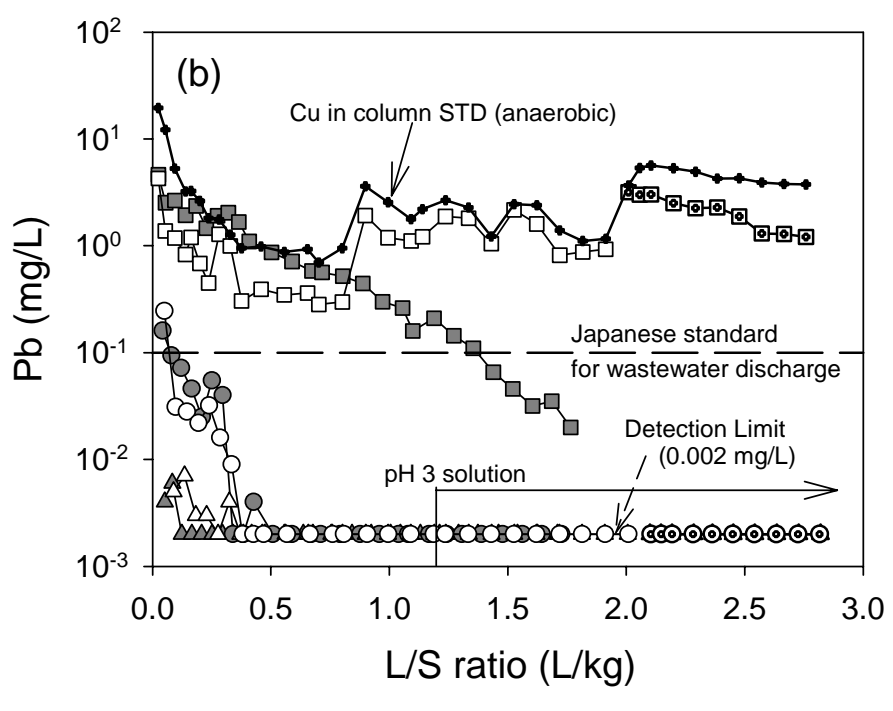

- Changed to aerobic column STD

A Changed to aerobic column W-C

- Changed to aerobic column C-P

Fig. 5 Concentrations of $\mathrm{Cu}$ and $\mathrm{Pb}$ as functions of $\mathrm{L} / \mathrm{S}$ ratio. 


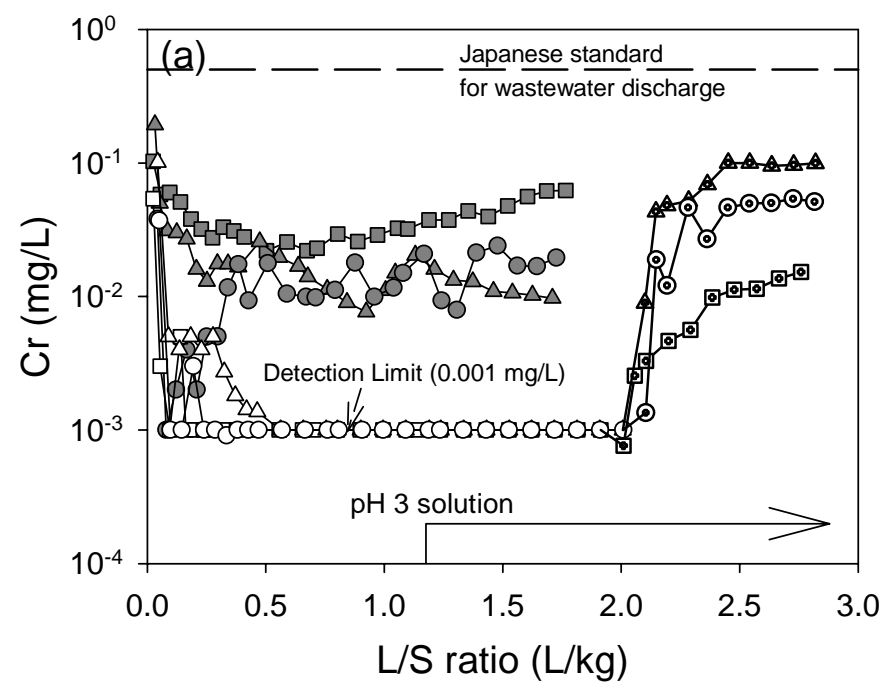

Fig. 6 Concentrations of $\mathrm{Cr}$ as functions of the $\mathrm{L} / \mathrm{S}$ ratio.
Aerobic column STD

$\triangle$ Aerobic column W-C

- Aerobic column C-P

Anaerobic column STD

$\triangle$ Anaerobic column W-C

- Anaerobic column C-P

q Changed to aerobic column STD

A Changed to aerobic column W-C

- Changed to aerobic column C-P 